\title{
Economic Independence Of The Village Through Institutional Village Enterprises (BUMDes)
}

\author{
Rachmat Hardijono ${ }^{1}$, Maryunani $^{2}$, A. Erani Yustika ${ }^{2}$, C. Fajri Ananda ${ }^{2}$ \\ ${ }^{1}$ Doctoral Program of Economics Science, Faculty of Economics \& Business, University of Brawijaya \\ ${ }^{2}$ Faculty of Economics \& Business, University of Brawijaya, Indonesia
}

\begin{abstract}
Rural development in developing countries, including Indonesia, will certainly relate to the issue of poverty reduction. One instance of the problem of poverty is rural economic governance institutions. In the perspective of the economic independence of the rural economy is an alternative institutional rational choice and unique, given the village often seen as a small, weak and underdeveloped. Therefore, to change the thoughts and views of the importance of a village in the emic perspective to try to strengthen economic institutions through village-owned enterprises (BUMDes).

This study aims to explain the phenomena of the institutional. BUMDes the main issues of governance, BUMDes as actors or institutions (organizations) in order to continue to grow the economy This study used a qualitative approach through the method of phenomenology, the locus of the suburban rural areas in Malang, East Java Province, Ketindan village and Wonorejo village, District of Lawang, and Gondowangi village, District of Wagir. Background for the site selection studies have established institution with its main business BUMDes on water management in order to meet the needs of the villagers.

The results of this research in theoretical and empirical perspectives (emic), shows that : (1). Institutional BUMDes refers to the maximization of utility as the goal, the maximization of profit (profit maximization), (2). The community of BUMDes Institutions are more likely to prioritize rationality villagers as a group, with social capital as the basis of individual interests and preferences; (3). BUMDes organizational structure that is outside the village government structures are not always stable and efficient in providing services to villagers., And (4). Villagers are assigned as officers and employees BUMDes more motivation and orientation based on the non-material, namely a sense of respect and appreciation socially and politically than economically.

BUMDes institutions to put forward the goal of maximizing the usefulness of water for the fulfillment of (welfare) villagers, rather than maximizing profit for increased revenue village (PADes). BUMDes governance implementation based on the perspectives, preferences, and commodities are produced according to the potential of each village.
\end{abstract}

Keywords: Rural Economy, BUMDes Governance, and Social Capital

\section{Introduction}

Problems of poverty and economic backwardness or gaps, both between groups and between regions (including between rural and urban areas) almost always been an interesting discussion. If we look a few decades ago, research Boeke (1983) conducted in Indonesia (Dutch East Indies) shows that the economic system, especially in Java, is divided into 2 (two) sector, which is the traditional sectors (agriculture/natural relies on) in rural areas, and modern sectors (industrial) in urban areas, both of which are separate and unrelated, but side by side. To overcome the gap as the implications of the dualistic economy is, furthermore Boeke (1983) recommends that the traditional sector received economic incentives and improvement of production technology, although its positive impact was not immediately appear.

Therefore, to release people from poverty, it is not possible to hold the construction in Indonesia without involving the rural areas. This is demonstrated by the fact that the majority $(56.86 \%)$ in the Indonesian population live in rural areas, so that the focus and target of development in order to the improvement of livelihoods (welfare) of the rural population also needs to be prioritized. Even the accelerated development of rural economy particularly in pockets of disadvantaged areas, should be a priority (Maryunani, 2007).

The acceleration of economic development in order to independence or sovereignty (strengthening ongoing basis) rural economy is crucial to do, and kept up to date to be studied further (Kalla, 2011). However, other experts such as Collier and Santoso (1996), and Hill (1996), and Arifin (2001) argues the opposite, ie any improvement efforts for rural or agricultural difficult to achieve even might not work. This is caused mainly by the ownership of capital (land) is very low in the traditional sector (rural or agricultural). In the perspective of rural with urban relationships, the most important principle is to harness economic resources and promote rural economic activity is maximal in the village through increased value-added economic activities. As one of the 
phases that need to be done in building the village is through the strengthening of the economic organization (institution).

Rural economic institutions to this day remains an important part, while still a weak point in order to achieve economic self-sufficiency of the village. This is apparent when observing the existence of cooperatives, especially the Village Unit Cooperatives (KUD) who has long been active with the ups and downs, but still quite a bit of performance (Rahardjo, 2011). Therefore, a systematic effort is still needed to encourage rural institutional capacity is to be able to manage the economic resources located in the village, as well as develop a network to improve the durability even possible economic competitiveness.

In the era of reform and decentralization in Indonesia in the late 1990s, through Law (UU) 22/1999 (article 108) has encouraged the formation or establishment of institutions or enterprises to manage their resources efficiently, although not explicitly stated the agency as BUMDes. Furthermore, Law (UU) 32/2004 (article 213) has been clearly and unequivocally offensive BUMDes existence as an element of rural finance, but its existence is explicitly suggested that rural enterprises to develop based on the needs and capacities possessed economy. In line with this spirit, article 78 paragraph (1) Government regulations (PP) 72/2005 states that "In order to increase villagers income village, the Village Government may establish village-owned enterprises in accordance with the needs and potential of the Village". The word "may" is not a must, or simply as an alternative (option). Ideally the existence of village enterprises become one of the functions of government is to manage the economic resources for the prosperity of society. The village requires an entity to manage its potential, because the village during this economic crash. In addition, the existence of the village in the system of government in Indonesia is to organize and serve and take care of the interests of society in order to help the realization of welfare. Briefly Explanation can be seen in Figure 1 below.

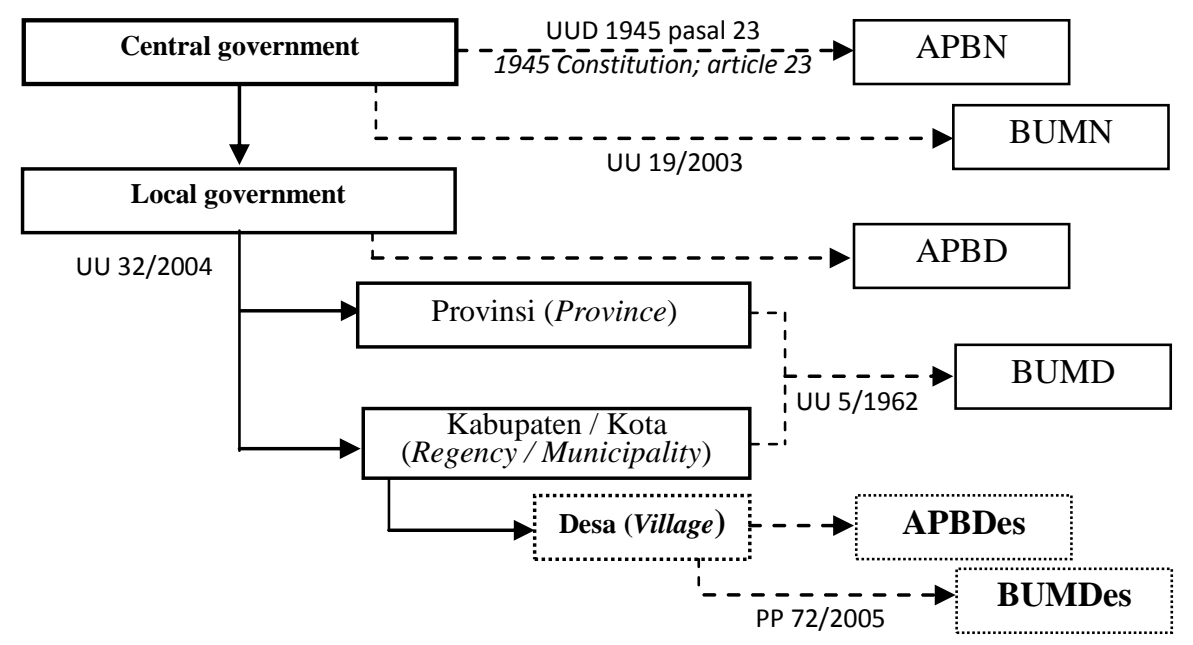

Source: constructed/processed from Asshiddiqie (2010); Wasistiono and Tahir (2007)

Fig 1 : Anatomy of Government of the Republic of Indonesia

In such a context, it appears that the existence of BUMDes is a form of consolidation or the institutional strengthening of rural economy. While the essence of an instrument BUMDes utilization of the local economy with a wide range of potential. Potential utilization is mainly aimed at enhancing the economic welfare of the villagers through their economic development efforts. In addition, the existence of institutions BUMDes directed to contribute to the improvement of village revenue sources (PADes), so the village is able to carry out the development and improvement of people's welfare more optimally.

If the terms of the concept (according to Law [UU] and PP), the formation of BUMDes to immediately realize the welfare of rural communities. But in terms of implementation, there are still many areas and villages that do not have the initiative and motivation to develop BUMDes intended. It can be seen from 378 villages in Malang, since the implementation of Law (UU) 32/2004 and Government Regulation 72/2005 and Regulation 20/2006, only 25 villages (6.6\%) that are nominally (set forth in Rule Village) has been formed BUMDes. However, the interesting part of this is BUMDes institutions that prioritize its founding purpose revenue (welfare) of society than of a village government revenue (APBDes). This is different, if the analogy with the existence of state-owned enterprises (BUMN) or regionally owned enterprises (BUMD) as a very large force for the future development of the Indonesian economy, which both give priority to foster income and at the same time contributor to the state budget revenue (APBN) or the regional budget revenue (APBD). Thus, BUMN and 
BUMD are more likely as a semi-public, while BUMDes unique as rural enterprises run by the government and local communities (local). Nevertheless, it seems that the independence and rural economic performance (including institutional BUMDes) not only based on traditional theories that rely on allocative advantages of decentralization. However, the performance of the local economy is largely determined by the behavior or governance itself is a concern of the new perspective theories.

Linkage complexity of rural development in order to improve the wellfare, independence, and sustainability of the village, this study is more focused on the economic capacity of the village as the village economy through the power of a touch of village-owned enterprises (BUMDes). The institutional BUMDes selection is based on considerations; First, that BUMDes an organization or institution that is relatively new, and is regarded as a simplification of BUMN or BUMD whose existence and management is still experiencing a debate. In fact, the village and BUMDes has a unique institutional economically, politically, and socially. Second, the conception of the formation of BUMDes is to increase incomes and rural needs and potential. Thus, if the Indonesian people mostly live in rural areas in poor condition as the implications of the theory of economic dualism according to Boeke that has been alluded to in the beginning, the success of development (in general) will be deemed to have touched most of its citizens.

To sharpen the analysis of institutional BUMDes (which includes governance, interaction, and the rules) as a study focus, political and economic theory of social capital theory put forward as a tool to answer the study problem formulation to achieve the goals of this study. The both essence of the theory (or other theories in institutional economics) is always incentive for individuals or communities to behave outside the common corridor (conventional) in an attempt to achieve its objectives. Thus, by simply controlling the market mechanism to make the economic system is not able to run effectively. Therefore, it seems BUMDes as nonmarket institutional (non-market institutions) so that the interests of rural communities and the government does not have problems with 'designing' institutional macro and micro level. At the macro level (institutional environment), BUMDes will contain a set of rules outlining the social and political economic activity. Furthermore, at the micro level (institutions of governance and institutional arrangements), will BUMDes institutional issues related to governance rules that activity among economic actors can still take place through cooperation or competition. In the presence of BUMDes in efforts toward economic independence of the village as the focus of study, then BUMDes can be viewed as an institution that has the character of the local economy is diverse and with varying expectations, there is even a "pessimistic considers" its action suit individual perspective. It is not the fault of thought or expectation, but BUMDes still be seen from the viewpoint outside the village (ethical perspective). Therefore, this study seeks to uncover BUMDes the view of the village community and the government itself (emic perspective), as well as an object and subject to village development activities in the region (locus and study sites), respectively.

This study aims to articulate BUMDes institutions and phenomena to uncover existing problems. Therefore, this study explains how governance in BUMDes (institutions of governance) as a rural economic institutions. This study was not intended to test or implement the theory in implementation BUMDes governance as one of the village economic institutions that are not only oriented to profit, then the output is expected to redesign rules (regulations) for institutional BUMDes. In addition, the following effects are expected to be able to reconstruct the theory (substantive) in particular the theory of rational choice or public choice theory is that during economic thinking tends to be colored by classical/neoclassical, the point that the measure of success or performance of an enterprise (company) is the efficiency or profit purely financial.

\section{Research Methods}

This study seeks to understand the behavior of individuals or communities in the "settings" (form or situations) specific social, as well as to answer questions concerning the study problems of governance BUMDes then used a qualitative research approach. A qualitative approach grounded in interpretive and constructive paradigm, which is very different from the positivist approach as quantitative research pillars (Sugiyono, 2010; Creswell, 2010).

The analysis in this approach is an attempt to understand the process and the facts, and not just tell the facts found, with design (strategy or procedure) specific (Bungin, 2008), namely :

a. Observing socio-economic phenomena that take place at the sites;

b. Identify, confirm and revise existing data;

c. Doing the category of the information obtained;

d. Explore and explain the categorization;

e. Interesting general conclusions;

f. Explain or build theory.

Qualitative research has a wide range of methods, one of which is a phenomenological research method. As part of a qualitative approach, the study of phenomenology was chosen by the researcher in order to 
be able to identify the nature of an individual or community experiences about a particular phenomenon (Creswell, 2010; Kuswarno, 2009).

\section{Objects, Units of Analysis, and Subject}

Object of this study at the same unit of analysis covering governance BUMDes with other economic institutions. While the subject of this study is to understand the people who own and information related to the management and maintenance of BUMDes and member/ordinary villagers who have attention or receive the benefits of the existence of BUMDes institutions, both as actors directly or through another person who understands the object of study. Therefore, this study is the subject of a resource or informants to uncover phenomena in institutional BUMDes.

\section{2 . Siting and Selection of Informants}

Malang as a locus of study-based considerations have had and implementing Regulation (Perda) 20/2006 on village-owned enterprises (BUMD) as the implementation of Article 81 of Regulation (PP) 72/2005 on the village. While rural areas are sampled Ketindan village and Wonorejo village, Lawang district, and Gondowangi village, Wagir district determined intentionally and 'equivalent' (apple to apple) to the 25 villages that already have a village regulations (Perdes) on the Establishment BUMDes.

This study was conducted in Kabupaten Malang (consisting of 136 villages that have received 'recognition' of the BUMDes, trhrough 378 in the village of Kabupaten Malang). Map of the study site can be seen on the map below.

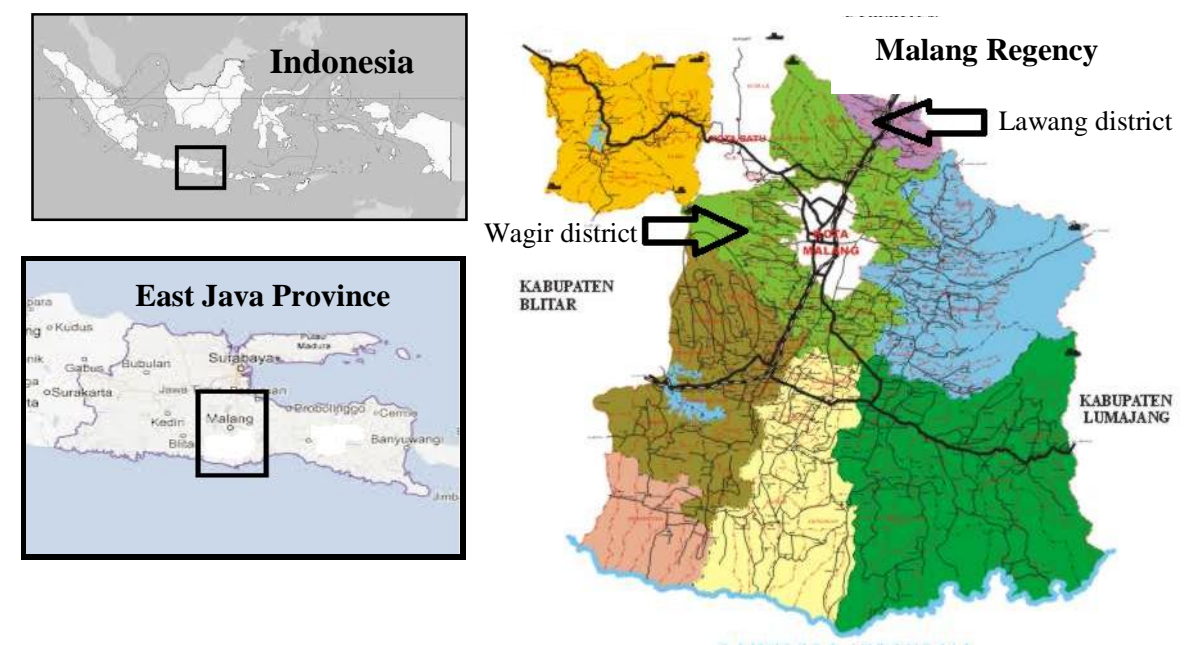

Fig 2 : Map of Location Research

\section{Data Collection Strategy}

Strategy or a way to gather and obtain data in qualitative research is common, namely : observation (observation), interviews (interviews), and documentation (documents), which can be supported in an audio recording devices and /or visual (audio-visual materials). In this study, conducted nonparticipant observation which means that researchers do not position themselves into villages, or 'officials' village, or management, or customer BUMDes at the study site. But only 'accompany or observe' them in their activities. If the presence of the researcher (are close in the physical sense) can disrupt their activities, then the observation in remote or indirectly by using the trust as an intermediary researchers.

Interview strategy was also used in this study through benchmark research questions that have been prepared. Reference questions intended to give directives (guidelines) for researchers or researchers in an effort to reveal the intermediary institutions BUMDes phenomenon. The researcher used the research questions or intermediary in interviewing informants conducted open-ended, in-depth, informal, and unstructured.

Documentary techniques in principle is a method used to explore historical data that are commonly used in social science research, especially the study of history. In this study also sought access to the documents referred to, among others, in the form of village rules, regulations/decisions village head, minutes of meetings, certificates, letters, and so on. Similarly with audio-visual data recording techniques that can be accessed by researchers in order to enrich the process of collecting and presenting data, and refine the analysis in this study.

\section{Analysis, Validity Test, and Model Discussion}

Given the research data obtained in the form of qualitative data (among other tangible statement, symptoms, nonverbal actions that can be recorded in the description sentences, or numbers, or pictures/photos, 
and so on), so in this study using data analysis model of Miles and Huberman (1992) through the activity/process called coding.

\begin{tabular}{|l|l|l|}
\multicolumn{2}{l}{ Data collection period } \\
\cline { 2 - 3 } & Data reduction & \\
\hline Anticipation & During & Post \\
\hline Data presentation & & \\
\hline \begin{tabular}{l|l|l|} 
During \\
Conclusion / verification
\end{tabular} \\
\hline During & Post & Post \\
\hline
\end{tabular}

Source : Miles and Huberman (1992)

\section{Fig 3: Flow Model Analysis of Qualitative Research Data}

Model analysis was conducted in three (3) activities and can take place in parallel as Figure 1, with a brief explanation follows:

a. Data reduction is the process of sorting, focusing, simplification, abstraction, and transform raw data that have been obtained from the process of data collection in the field;

b. Presentation of data, carried out by preparing a series of information allowing for the extraction of data and making conclusions recommendations. In this activity, the researchers attempted to use way to present it in the form of narrative text, charts or graphics/groove, and matrix/table can text through content analysis; Content analysis is simply defined as a method to collect and analyze the payload of a "text" that departs from the axioms and is the basis of all social sciences, although it originated from the positivistic paradigm (Muhadjir, 2002). Text can be words, sentences, meaning pictures, symbols, ideas, themes and various forms of messages that can be communicated.

c. Conclusions that have been drawn, and then verified during the study. Verification is a review or thinking back on the results of field notes which may have lasted a glimpse or take a long time, as well as brainstorm (discussion) with informants to develop a meaning that can be done through focus group discussions (FGD). Meanings that emerge from the data needs to be tested its validity by means of triangulation (including the credibility of the test data through member check/triangulation ${ }^{3}$ of data sources) in order to establish its validity.

The activities are not only partial, but inter-related, simultaneous and continuous so that it becomes a cycle (interactive model) which can be simplified as in Figure 4.

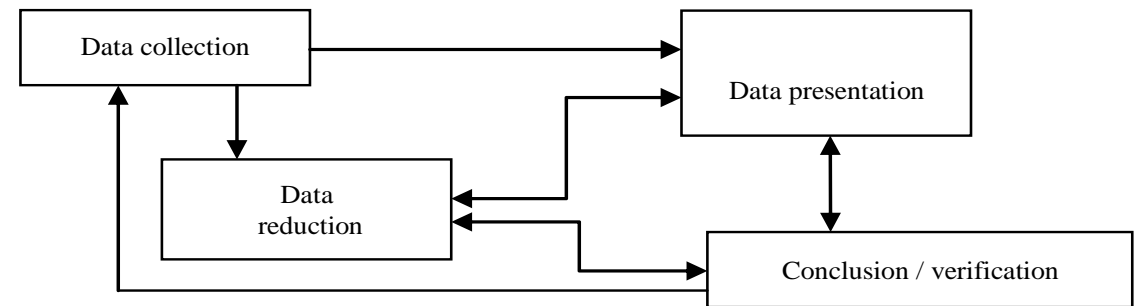

Source: modified from Miles and Huberman (1992)

Fig 4: Model of Interactive Data Analysis Qualitative Research

In the methodology to be achieved in the analysis of qualitative data in institutional BUMDes the focus of this study are: (1). Analyze the ongoing process of economic and social phenomena acquire complete description of the process, (2). Analyzing the meaning behind the data, information, and processes of a phenomenon referred to (Bungin, 2008).

From the analysis and validity test of the data as outlined in the discussion (data display), and that the presentation of the data can be understood or have meaning and depth explanation methodologically, it is no less important is the meaning in accordance with the conditions that we want to know. The meanings determine the weight or quality of the study, so the discussion in writing of the results of this study the researcher attempted to construct a knowledge through scientific ways of thinking, as one of the benefits (contribution) research. The 
way of thinking is done with the analysis based on the dialectic of reflective thinking that is simply presented in figure 5 .

Triangulation is one way to test the validity of research results in various ways and at various times, by utilizing the ' honesty ' that exist in the research, sources of data (can be through the member check), methods techniques, and theory (Bungin, 2008; Sugiyono: 2010; Creswell, 2010). This test is to ensure that the research conducted will be more accurate, because the information is obtained from various sources (informants ) and the specific process, thereby stimulating researchers to develop a display of data that is accurate and credible (Emzir, 2010)

Reflective thinking is defined by Bungin (2008) as " autonomous researcher/writer ", so the author is allowed to improvise by explaining basic scientific assumptions. This section termed " scientific adventure writer ", because the authors are interested in and also have the opportunity to express thoughts and ideas are correct according to the author in accordance with his beliefs, experiences or observations in the study, and the theoretical knowledge they have learned.

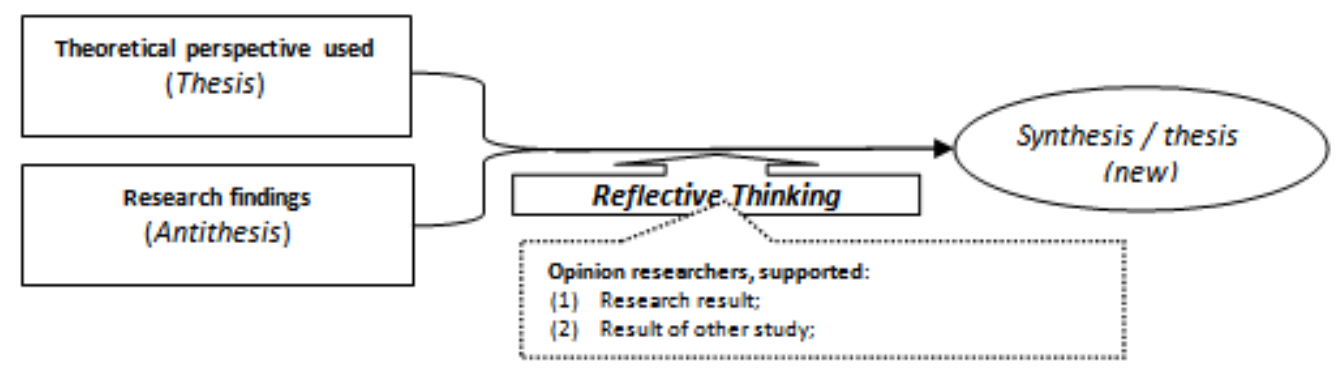

Source: modified from Bungin (2008).

Fig 5: Model Discussions Study Report

The discussion in this research report are reviewed to obtain empirical explanation and methodological. Further important findings of a dialogue with the perspective of the relevant theories, so that the theories can be developed or reconstructed (synthesis / new thesis).

\section{Empirical Result}

The results of this study are based on data mining in the field and connected with research methods and articulate with relevant theoretical perspectives. In substantive results of this study explain that the economic governance BUMDes with village based reflective thinking is:

a. Findings 1: Governance BUMDes oriented, For Maximizing Usability

Design BUMDes organization studied is not only to manage water as a commodity tends rare. That is, the scarcity of clean water can be a starting point to explore the institutional BUMDes. BUMDes studied appear to be inherent in the organization's governance structure, or physically separated from the structure of village government, but the essence is still bound to the social function of the village concerned. Rationality on the choice of the form of organization BUMDes intended to build an organization that is productive (profitable) and independent (self/free of power) as the restoration and improvement of public management, as well as appeared as a reaction to the criticism of the Weberian model of bureaucracy (Osborne and Gaebler, 1996). In BUMDes institutions there is decentralization of power to the bottom and separate structures that BUMDes governance, standard operating procedures are elastic, the presence of creativity and innovation, clear hierarchies of power, as well as staffing system/its staff a more competitive and open.

However, BUMDes are facing internal problems (conflict management, and mind [protest] from customers), it turns back to the 'influence' of village government elite as reviewed by Shepherd (in Darmawan, [2006]; Ellis and Biggs in Yustika [2008]). It can be seen from the fact that research on the BUMDes Gondowangi formal legally choose progressive tariff scheme as the classical economic concept/neoclassical for pricing water consumption or cost. On the other hand, especially the village of Gondowangi (especially customers BUMDes) who prefer a collaborative way to determine water rates. Its meaning, rural communities in the study believed that the rate or price is measured from the amount of money as a symbol of materialism in the classical economic concept/neo-classical model of incentives or disincentives is not the most effective way to maintain the benefits of clean water. But with mutual aid in 
community activities (customer BUMDes Tirto Ageng Gondowangi village), or the attitude of patience and saving, as well as understanding of the villagers (customer BUMDes Tirto Langgeng Ketindan village and villagers Wonorejo) to use water turned out to further improve the benefits of clean water, and most importantly, do not lose water utility for the customer/other villagers. This means that the behavior of mutual assistance, patient attitude or saving, as well as mutual trust, and confident (believe) among the villagers is a form of social capital, as well as the 'resistance' price mechanism (raise rates).

The decision to require a specific thing as a BUMDes governance done on the basis of local potential that is in each village. That is, options (normatively) to form/structure based organization thought BUMDes reinventing government or by the type of Weberian bureaucracy is reflected in the standard operating procedures, creativity and innovation, as well as the power level of the employment system.

In the management of water resources by BUMDes, is an effort to provide clean water for villagers who aimed to improve the lives of people at the community level with the village government is 'self-managed'. The meaning of self-management is to promote the spirit of mutual cooperation that is based on a sense of the villagers, the commitment to realize a better life with emphasis on common interests. This proved to be a 'powerful moment' when faced with the question of the funding requirements for the development of utility networks. In fact, if you adopt the ideas of the classical/neoclassical is by raising rates (the price of water) so that the funding needs can be satisfied, and can make a profit for the maximally BUMDes (Deliarnov, 2005; Skousen, 2006) considering the profit $(\pi)$ is total revenue (TR) minus total cost (TC), and $\mathrm{MR}=\mathrm{MC}$. These conditions indicate that the orientation BUMDes still tied to local wisdom, namely the maximization of benefits of clean water for villagers.

Proposition 1 : Institutional BUMDes refers to the maximization of utility as the goal, the maximization of profit.

b. Findings 2 : BUMDes governance tends to be more community based groups and emphasizes the rationality of social capital.

Private rights according to classical thought/neoclassical only be efficient if the owner can enjoy or make use of it. While that is not the owner should be excluded from the use of the property right. However this could potentially lead to a prolonged conflict, so that ownership rights should be set and enforced for the system to be more efficient economy (Prasad, 2003). While the socialist economic system (socialism) that put the factors of production (means of production) in the control of the state government. Production and investment are not determined by market mechanisms and by the capitalists (the private sector), but done with centralized planning by the government (Karl Marx in Deliarnov, 2006)

Table 1: Comparison of Conventional Economic Paradigm and Political Economy in the village over BUMDes Institution Ketindan and Wonorejo village, Lawang district, and Gondowangi village, Wagir district, Kabupaten Malang, 2011

\begin{tabular}{|l|l|l|}
\hline \multicolumn{1}{|c|}{ Paradigm } & \multicolumn{1}{c|}{ Clasic / Neoclasic } & \multicolumn{1}{c|}{ Rational Choice } \\
\hline Providers (supplier) & Manufacturer,entrepreneurs, distributors & BUMDes and/or Village Government \\
\hline Users (demander) & Consumer & Villagers dan/or customer BUMDes \\
\hline Commodities & Individual comodity (private goods) & Clean water as public commodity (public goods) \\
\hline $\begin{array}{l}\text { The purpose of the } \\
\text { transaction }\end{array}$ & $\begin{array}{l}\text { Maximization of profit (profit) through price } \\
\text { discrimination (rates) }\end{array}$ & $\begin{array}{l}\text { Maximization of utilityn (utility) of clean water to the } \\
\text { villagers a sense of togetherness }\end{array}$ \\
\hline Type of transaction & Voluntary transactions & Confidence (trust) and faith (believe) \\
\hline Power structure & Presented itself (given) & $\begin{array}{l}\text { Formed in a rational society limited (bounded rationality) } \\
\text { and opportunistic behavior(opportunistic) of the individual } \\
\text { as a member of the village community }\end{array}$ \\
\hline $\begin{array}{l}\text { The role of state } \\
\text { government }\end{array}$ & Avoid, or even eliminated & $\begin{array}{l}\text { It is expected, even required to maintain harmonization and } \\
\text { stabilization }\end{array}$ \\
\hline
\end{tabular}

Sources : compiled from the research (based on field data and re-conceptualization of Rachbini, 1996, Political Economy: Paradigms, Theory, and New Perspectives, Cides. Jakarta: 50)

The role of government according to the neoclassical approach is based on the premise that puts the individual as "constrained choice" (limited choice). In this view, individuals as agents who decide or choose (choosing agent) rationally from several alternatives in situations of scarcity. Scarcity occurs when there is a gap between the subjective conditions (desire) with objectif conditions (availability of resources). The best way for individuals to make decisions in situations of scarcity is through a market mechanism, so the market should be strengthened and maintained its existence so that economic activity can continue (Caporaso and Levine, 2008) .

In the perspective BUMDes water management as a relatively limited resources, the individual and a member of the village community faced with the choice of receiving the alternative tariff adjustment (the price of water) as the implications of the market mechanism, or alternative action individually and communal impact on mutual benefit. Concrete, for villagers Ketindan addressed with the use of water- 
saving and patient behavior, so that other people can also enjoy. For Wonorejo villagers are using clean water upon mutual agreement and enforced by the village government explicitly, ie water for human needs first, and subsequent livestock and crops. While Gondowangi villagers react to the activities of mutual aid to "fight" option to raise water rates to repay the loan. Patient attitudes and behavior, saving, mutual trust to take advantage of the limited fresh water is a few dimensions and applications of social capital. The social capital is in response to the management of limited water resources to be used together.

Proposition 2 : Institutional BUMDes the community are more likely to give priority to the rationality of the community as a group, with social capital as the base of interests and preferences of individual.

c. Findings 3 : The rationality of the choice of organizational form BUMDes is located outside the village government structure, or inherent in the functioning of Village Government.

BUMDes institutional design on a macro level (institutional environment) both listed in local regulations (Perda) 20/2006 and Ministry of home affairs regulations (Permendagri) 39/2010, requires that BUMDes managed by village governments and local communities-the villages or a separate organization outside the government structure of the village. However, the provisions contained in the formulation advantages and weakness that make it possible implementations applied differently. The difference is understood that the management BUMDes 'must be' separately from the village government structure as that applied by BUMDes Tirto Langgeng Ketindan village, and the BUMDes Tirto Ageng Gondowangi village. That is, the structure and function including personnel (managers) of BUMDes can not 'concurrently ' by the village head and village officials. Concretely, the Village Head Ketindan positioned as a builder and supervisor, or a kind of 'commissioner' top BUMDes, and the Village Head Gondowangi only positioned as a 'protector', considering there is a separate agency as Supervisor and Examiner BUMDes. While Wonorejo village that adheres BUMDes structure separate from the village government, but its function remains the responsibility of the village because it is normatively manager BUMDes government and villagers. So BUMDes governance by village officials (ex-officio) which is a rational choice for stabilization and efficiency of service.

If related to the opinion of Miller (1992), suggests that the rational choice approach is weak experienced in the institution BUMDes Tirto Ageng Gondowangi village. This is indicated by the presence of rational disagreement between individuals and even groups on the one hand that is trying to boost revenue with an option to raise the tariff, and the emergence of social and institutional barriers from others. While the hard approach (strong approach) as an option of BUMDes Wonorejo a reaction of social and institutional barriers that lead to the choice to act rationally to 'synergize' between BUMDes management and government to maximize the usefulness (utility maximization ) of clean water. In addition to Wonorejo villagers, choice of organizational form BUMDes are 'attached' to the village government is an effort to efficiently and effectively to eliminate individuals who act/behave rationally to achieve their own interests. As for the case BUMDes Tirto Langgeng Ketindan village which is a completely separate organization from the village government structure, it is internally not have problems socially and institutionally, because almost all of its leaders is former village officials. It is a manifestation of trust and appreciation for the devotion of the villagers, and their patience availability of water to serve better. In summary, the third BUMDes studied had different intensity in village government involvement or intervention in its management, the formulation of policies/plans as well as its operation. In terms of monitoring the BUMDes governanace conducted by the Head Village to BUMDes Tirto Langgeng, Village Consultative Council for BUMDes Wonorejo, and a separate Institute for BUMDes Tirto Ageng.

Proposition 3 : BUMDes organizational structure that is outside the village government structures are not always stable and efficient in providing services to villagers.

d. Findings 4 : Management, staffing and customer relations BUMDes based on the non-material motivation and orientation.

From the study of institutional BUMDes conducted showed that management and employee motivation is not always based on financial interests. That is, with the salary/wages as officials or employees who are still below Rp.750 thousand (even for non-permanent employees/odd only paid Rp. 30 thousand), still has a high dedication and loyalty to the execution of tasks in BUMDes to serve customers will need clean water. It is based on considerations of non-material, the orientation of the social role and functional. Concretely, that the administrators who do not have background reprehensible behavior, has a great chance of success ( Wallis, et al. , 2004). In addition to the response of the villagers to management of Tirto Langgeng BUMDes also as a form of social capital in the form of positive appreciation, so that its staff can continue. The promotion of social return on capital management, and staffing patterns in order to be effective rural poverty reduction (Abdul-Hakim, et al. , 2010).

Somewhat different from the situation in BUMDes Wonorejo stable given its staff 'attached' to the village government, but to BUMDes Tirto Ageng more dynamic because there is political influence (power latent 
conflict) of excesses village elections in 2008. But both the fixed forward BUMDes aspects of service and maximization of utility on the use of clean water for villagers.

Proposition 4 : Citizens are assigned as officers and employees BUMDes more motivation and orientation based on the non-material, namely a sense of respect and appreciation socially and politically than economically.

\section{Conclusion}

Referring to the explanation of the phenomenon exists and disclosure Governance BUMDes reality, then some of the recommendations from the results of the research are expected to strengthen the rural economic institutions, namely:

First, open up opportunities for the business entity does not always make sense as a legal entity which tend to be oriented on economic benefits (profit). However it can also be interpreted as a business entity that seek to improve services according to the needs and character of the local community. A concrete acknowledge and positioning that BUMDes uncertain as the company, but an institution Public Service Agency Village (BLUDes) which is a government entity outside the village with assets that are not separated so that aspect is not neglected by the public services rather than an increase in village budget revenue (PADes). BUMDes keep applying governance principles (good governance) and pour in the internal and formal rules (Village rules, Statutes(AD) and Bylaw (ART)) BUMDes.

Second, the shape of BUMDes interaction with other institutions such as co-operation should be facilitated and protected by the village government and/or local governments, especially the existence and sustainability of emerging BUMDes can be maintained. Concrete, at the beginning of its establishment is not burdened with the obligation to 'deposit' or 'collecting money' for activities that are not proportional . In addition, the role and involvement of the 'leaders' of society and village governments that have high social capital can be 'attached' as caretaker BUMDes to increase access to cooperation with other parties for the betterment BUMDes.

Third, the BUMDes institutional rules in general so simplified and aligned with the essence of the village as a legal public entity with authority to regulate and manage the interests of the local community, based on the origin, and the local customs are recognized and respected. It can be interpreted that the need to redesign the rules and regulations especially Regional Regulation and Villages Regulation concerning the certainty and regularity and continuity of the service/interests of rural communities that are preferred, rather than short-term profit orientation. Similarly, from the licensing aspect that needs to be facilitated by the scale or scope adjusted BUMDes are still at the level of the village or between villages. In addition, incentives in the form of tax refunds are paid BUMDes multiplier effect can spur economic and social activities in the village in question and the surrounding villages. Synchronization provisions regarding the authority and presence BUMDes as subsystems of drinking water supply system (SPAM) need to be clarified and reinforced. This is so that BUMDes can help support the acceleration provision of drinking water for rural communities, and to catch up facilities in urban areas are more established are handled by regional enterprises (PDAM) .

\section{References}

[1]. Abdul-Hakim, R., Abdul-Razak, N.A., Ismail, R. 2010. Does Social Capital Reduce Poverty? A Case Study of Rural Households in Terengganu, Malaysia. European Journal of Social Sciences, Vol. 14, No. 4: 556-566.

[2]. Boeke, J.H. 1971. Batas-batas dari Masyarakat Pedesaan di Indonesia, LP3ES. Jakarta.

[3]. 1983. Prakapitalisme di Asia, Sinar Harapan. Jakarta.

[4]. Budiman, A. 1995. Teori Pembangunan Dunia Ketiga, Gramedia Pustaka Utama. Jakarta.

[5]. Bungin, H.M.B. 2008. Penelitian Kualitatif: Komunikasi, Ekonomi, Kebijakan Publik, dan Ilmu Sosial Lainnya, Kencana (Prenada Media Group). Jakarta.

[6]. Creswell, J.W. 2010. Research Design: Qualitative, Quantitative, and Mixed Methods Approaches. Achmad Fawaid (penerjemah). Research Design: Pendekatan Kualitatif, Kuantitatif, dan Mixed, Pustaka Pelajar. Yagyakarta.

[7]. Deolalikar, et.al. 2002. Poverty Reduction and the Role of Institutions in Developing Countries. ERD Working Paper. No. 10 Asian Development Bank.

[8]. Dequech, D. 2002. The Demarcation between the "Old" and the "New" Institutional Economics: Recent Complications, Journal of Economic Issues. Vol. XXXVI, No.2 June: 565-572.

[9]. Ekelund Jr., R.B., Hébert, R.F. 2007. A History of Economic Theory and Method (Fifth Edition). Waveland Press, Inc. Ilinois

[10]. Franke, S. 2005. Measurement of Social Capital: Reference Document for Public Policy Research, Development, and Evaluation, Report to the Policy Research Initiative (PRI), September, Ottawa, Canada.

[11]. Fukuyama, F. 2005. The Great Disruption: Human Nature and the Reconstitution of Social Order. Masri Maris (penerjemah). Guncangan Besar: Kodrat Manusia dan Tata Sosial Baru, Gramedia Pustaka Utama. Jakarta.

[12]. Giddens, A. 2010. The Constitution of Society: Outline of the Theory of Structuration. Maufur dan Daryatno (penerjemah). Teori Strukturasi: Dasar-Dasar Pembentukan Struktur Sosial Masyarakat, Pustaka Pelajar. Yogyakarta.

[13]. Glascock, A. P., Kutzik, D. M. 2010. The Capital Use of Social Capital or How Social Capital is Used to Keep Capital Concentrated. International Journal of Social Inquiry, Vol. 3, No. 2: 101-119. 
[14]. Gregg, S. 2010. Smith Versus Keynes: Economics and Political Economy in the Post-Crisis Era. Harvard Journal of Law \& Public Policy, Vol. 33, No. 2 Spring: 443-464.

[15]. Jaya, W.K. 2010. Kebijakan Desentralisasi di Indonesia Dalam Perspektif Teori Ekonomi Kelembagaan, Pidato Pengukuhan Jabatan Guru Besar dalam Ilmu Ekonomi, Universitas Gadjah Mada. 23 Desember.

[16]. Kalla, M.J. 2011. Kemajuan Ekonomi, Kewirausahaan, dan Kemandirian Bangsa, Orasi Akademik Penganugerahan Gelar Doktor Kehormatan Bidang Pemikiran Ekonomi dan Bisnis, Fakultas Ekonomi dan Bisnis Universitas Brawijaya. 8 Oktober.

[17]. Kuswarno, E. 2009. Fenomenologi: Konsepsi, Pedoman, dan Contoh Penelitian Komunikasi, Widya Padjadjaran. Bandung.

[18]. Martins, N. 2011. Sustainability Economics, Ontology and the Capability Approach. Ecological Economics, No. 72 : 1-4.

[19]. Maryunani (ed.). 2002. Alokasi Dana Desa: Formulasi dan Implementasi, LPEM Fakultas Ekonomi Universitas Brawijaya. Malang.

[20]. 2007. Sentuhan Pembangunan Ekonomi Dalam Penguatan Perekonomian Desa di Indonesia, Pidato Pengukuhan Guru Besar dalam Bidang Ilmu Ekonomi Pembangunan, Fakultas Ekonomi Universitas Brawijaya. 22 Oktober.

[21]. Muhadjir, N. 2002. Metodologi Penelitian Kualitatif, Rake Sarasin. Yogyakarta.

[22]. Munawar. 2007. Kritik Sosiologis Terhadap Kedudukan Individu Dalam Bangunan Teori Ekonomi Neoklasik, Pidato Pengukuhan Guru Besar dalam Bidang Ilmu Ekonomi Makro, Fakultas Ekonomi Universitas Brawijaya. 10 Desember.

[23]. Naghavi, M. A. S., Salavati, A., and Movahed, E. S. B. 2011. Public Sector Success in Social Capital: A Comparative Study in Iran's Governmental and Private Banks, European Journal of Social Sciences, Vol. 24, No. 1: 33-41.

[24]. Prasad, B.C. 2003. Institutional Economics and Economic Development: The Theory of Property Rights, Economic Development, Good Governance and the Environment. International Journal of Social Economics. Vol. 30, No. 6: 741-762.

[25]. Ritzer, G., Smart, B. (eds.). 2012. Handbook of Social Theory. Imam Muttaqien dkk. (penerjemah). Handbook Teori Sosial, Nusa Media. Bandung.

[26]. Rutherford, M. 2001. Institutional Economics: Then and Now. Journal of Economic Perspectives. Vol.15, No. 3 Summer: $173-194$.

[27]. Sen, A. 2007. Identity and Violence: The Illusion of Destiny. Arif Susanto (penerjemah). Kekerasan dan Ilusi tentang Identitas, Marjin Kiri. Serpong-Tangerang.

[28]. Skousen, M. 2006. The Making of Modern Economics: The Lives and Ideas of Great Thinkers. Tri Wibowo Budi Santoso (penerjemah). Sang Maestro Teori-teori Ekonomi Modern: Sejarah Pemikiran Ekonomi, Prenada Media. Jakarta.

[29]. Smelser, J. 1987. The Sosiology of Economic Life. Hisymi Ali (penerjemah). Sosiologi Ekonomi, Bahana Aksa. Jakarta.

[30]. Sobel, J. 2002. Can We Trust Social Capital?. Journal of Economic Literature. Vol. XL March: 139-154.

[31]. Srinivasan, T.N. 2000. The Washington Consensus a Decade Later: Ideology and the Art and Science of Policy Advice.The World Bank Research Observer, Vol. 15, No. 2: 265-270.

[32]. Stiglitz, J.E. 2003. The Roaring Nineties: A New History of the World's Most Prosperous Decade. Aan Suhaeni (penerjemah). Dekade Keserakahan: Era '90-an dan Awal Mula Petaka Ekonomi Dunia, Marjin Kiri. Serpong-Tangerang.

[33]. Sugiyono. 2010. Metode Penelitian Kuantitatif, Kualitatif, dan R\&D, Alfabeta. Bandung.

[34]. Sukidin. 2009. Sosiologi Ekonomi, Center for Society Studies (CSS). Jember.

[35]. Vel, J. 2010. The Uma-Economy: Indigenous economics and development work in Lawonda, Sumba (Eastern-Indonesia). Myrne Tehubijuluw-Umboh (penerjemah). Ekonomi-Uma: Penerapan adat dalam dinamika ekonomi berbasis kekerabatan, HuMa; Van Vollenhoven Institute; KITLV. Jakarta.

[36]. Woolcock, M., Narayan, D. 2000. Social Capital: Implications for Development Theory, Research, and Policy. The World Bank Research Observer, Vol. 15, No. 2: 225-249.

[37]. Yustika, A.E. 2003. Industrialisasi, Urbanisasi, dan Sektor Informal: Perspektif Kebijakan Lokal. dalam Iwan Triyuwono dan Ahmad Erani Yustika (eds.), Emansipasi Nilai Lokal: Ekonomi dan Bisnis Pascadesentralisasi Pembangunan, Bayumedia Publishing. Malang: 33-50.

[38]. 2008. Ekonomi Kelembagaan: Definisi, Teori, dan Strategi, Bayumedia Publishing. Malang.

[39]. 2009. Ekonomi Politik: Kajian Teoretis dan Analisis Empiris, Pustaka Pelajar. Yogyakarta.

[40]. Zhang, S., Anderson, S.G., Zhan, M. 2011. The Differentiated Impact of Bridging and Bonding Social Capital on Economic WellBeing: An Individual Level Perspective, Journal of Sociology \& Social Welfare, Vol. XXXVIII, No. 1 March: 119-142. 